$7-2-2012$

\title{
The Imperial Scholar Revisited: How to Marginalize Outsider Writing, Ten Years Later
}

Richard Delgado

University of Alabama - School of Law, rdelgado@law.ua.edu

\section{Recommended Citation}

Richard Delgado, The Imperial Scholar Revisited: How to Marginalize Outsider Writing, Ten Years Later, (2012).

Available at: https://scholarship.law.ua.edu/fac_working_papers/226

This Working Paper is brought to you for free and open access by the Faculty Scholarship at Alabama Law Scholarly Commons. It has been accepted for inclusion in Working Papers by an authorized administrator of Alabama Law Scholarly Commons. 


\section{FOR EDUCATIONAL USE ONLY}

140 U. Pa. L. Rev. 1349

University of Pennsylvania Law Review
April, 1992

*1349 THE IMPERIAL SCHOLAR REVISITED: HOW TO MARGINALIZE OUTSIDER WRITING, TEN
YEARS LATER

Richard Delgado [FNd1]

Copyright (c) 1992 by the University of Pennsylvania; Richard Delgado

INTRODUCTION

Ten years ago I began writing an article, The Imperial Scholar: Reflections on a Review of Civil Rights Literature, [FN1] that became one of the more controversial pieces of its time. It has been cited more than fifty times, as often without approval as with. Even as sympathetic a coreligionist as Derrick Bell describes the article as "'an intellectual hand grenade, tossed over the wall of the establishment as a form of academic protest."' [FN2]

In it, I showed that an inner circle of twenty-six scholars, all male and white, occupied the central arenas of civil rights scholarship to the exclusion of contributions of minority scholars. [FN3] When a member of this inner circle wrote about civil rights issues he cited almost exclusively to other members of the circle for support. [FN4] I argued that this exclusion of minority scholars' writings about key issues of race law caused the literature dealing with race, racism, and American law to be blunted, skewed, and riddled with omissions. [FN5] Among the reasons for the curious citation practices I discovered were (1) the mistaken belief that minority authors who write about racial issues are not objective, (2) the mainstream $* 1350$ writers' need to remain in control, thus ensuring that legal change does not occur too quickly, and (3) the sense of personal satisfaction resulting from being at the forefront of a powerful social movement. [FN6]

I concluded that article by urging minority students and teachers to question insistently and to improve upon the unsatisfactory scholarship produced by the inner circle, and by encouraging white liberal authors to redirect their energies towards other areas. [FN7] Although the article provoked a storm when it appeared, many of its premises and assertions seem commonplace today. [FN8]

This Article is a sequel to The Imperial Scholar. In it, I address the "second generation" question: What happens when a group of insurgent scholars gains admission, gets inside the door, earns the credibility and credentials that warrant consideration by mainstream scholars? Are these new scholars promptly granted equal standing, integrated fully into the conversations, colloquies, footnotes, and exchanges that constitute legal-academic discourse on issues of race and equality? Or, are they still marginalized, muffled, and kept in limbo-to be seen, perhaps, but not heard? [FN9]

To focus the inquiry, I limit my examination to two groups of insurgent scholars, Critical Race Theorists and radical feminists. These scholars were barely beginning to make themselves heard, were still marginal to the mainstream discourse, at the time The Imperial Scholar was written. Currently, members of these groups teach at the top law schools and publish in the best law reviews. [FN10] Their work is subject to commentary by distinguished colleagues $* \mathbf{1 3 5 1}$ and critics in top reviews, [FN11] and their controversies are covered by the New York Times and The Nation. [FN12] Even if not in the living room, they are plainly somewhere "inside the door." What reception are they receiving?

Part I of this Article examines their treatment at the hands of the original twenty-six "imperial scholars." Has this group's citation practice changed, now recognizing the new voices, 
perhaps as a result of reading works such as The Imperial Scholar? Part II then examines how the two insurgent groups are cited by mainstream scholars generally.

My conclusion is that mainstream figures who control the terms of discourse marginalize outsider writing as long as possible. In what follows I do not attempt to "prove" that this conclusion is correct as such. Rather, I simply catalogue the panoply of mechanisms employed by mainstream writers to cope with and keep at a distance outsider scholarship they find threatening. Although examples of each such mechanism are provided, they are not multiplied unnecessarily. [FN13] My intent is not to bring all the guilty parties immediately to justice; some may yet reform themselves. Indeed, it is my hope that this Article will provide the occasion for mainstream writers who recognize themselves in its pages to reevaluate their scholarly practices with respect to insurgent scholars. At the same time, I hope it will assist insurgent scholars in articulating their criticisms of unregenerate attempts to keep them on the margin.

The continued marginalization of outsider scholars, while perhaps distressing for the cause of social reform, should not come as a surprise. It is what we might expect from our studies of narrative theory paradigm shifting, concepts described in Part III. Reform tends to be slow and incremental; new knowledge strikes us $* 1352$ as extreme, coercive, "political," or strange. Yet even if natural, this resistance proves self-defeating, depriving us of points of view that we need for a more comprehensive view of the world. Sometimes, though, I suspect that resistance is based upon sloth, entrenchment, or sheer hostility to that which is new. Whatever its cause, the phenomenon is widespread enough to suggest that without real effort on our part resistance to reform may become a standard feature of our intellectual landscape.

\section{WAYS OF COPING}

This Part describes the ways in which the group of twenty-six scholars examined in The Imperial Scholar [FN14] have dealt with the growing body of outsider writing. There I showed that when the insurgents begin knocking at the door, they are ignored as long as possible. Once they gain admission, [FN15] the situation becomes more $* 1353$ complex. Some inner circle writers abandon the field. Others remain, but retain the habit of ignoring scholarship they wish not to recognize. Still others use a series of mechanisms to muffle and tame the new, divergent scholarship. Finally, some members of the inner circle have begun to integrate the outsiders' scholarship into their own writing and thought.

\section{A. Abandonment of the Field}

Most civil rights writing published in the top law reviews these days is written by women and minorities. [FN16] As new writers have entered the field, established ones have either reduced their production or left the field entirely. What Judge Wyzanski called the "minstrel show" [FN17]-black rights being enforced and interpreted by white men-is finally coming to an end. Part of the abandonment is simply due to increasing age: some of the great names of ten years ago have died or retired. [FN18] Others are moving into the $* \mathbf{1 3 5 4}$ golden part of their careers in which heavily documented and supported scholarship can give way to "reflections," opinion pieces, and musings that rely not on the careful analysis and painstaking research of traditional articles but on the strength of a reputation built by such analysis and research. [FN19] The aging of the inner circle alone, however, does not account for the entire shift in the demographics of authorship on race or gender and the law.

Rather, many inner-circle writers have moved to other fields. [FN20] Perhaps they do not see race and women's issues as the urgent topics they were in the 1960s and 70s. Many are now writing about jurisprudence, federal courts, constitutional interpretation, and strict construction, issues our more conservative times have placed on the front burner. [FN21] In the case of some, it could be argued that they moved on to bigger and better things. [FN22]

It may be, as well, that as the recognition of female and minority voices increases, some members of the inner circle find their efforts neither as necessary nor as productive as they once were. When a middle-class, white male scholar sees articles written by outsider $* \mathbf{1 3 5 5}$ scholars published in the top law reviews, he may well ask himself why he should continue 
writing about those same issues, with which he has a much more tenuous connection. Perhaps he wrote, in part, out of generosity or a sense of social obligation. Now that others have taken up the torch, his efforts may seem less necessary.

The field of civil rights has not been given over entirely to minority and feminist scholars, however. Nor am I arguing that it should be. For one thing, while males are affected to some degree by issues of racial justice. [FN23] Moreover, we certainly do not need ghettoization; the cross-fertilization resulting from integrated scholarship can be as beneficial as recognition of long-neglected voices. The inner-circle writers who continue to write about civil rights are examined next.

\section{B. Those Who Stayed}

The original inner-circle scholars who continue to write about civil rights can be divided into three subgroups according to their treatment of the new scholarship. Some have proceeded as they always did, virtually oblivious to the voices of those who are in many ways the subjects of the imperialists' writing. These scholars I call the Unconverted. A second, more interesting group has acknowledged the insurgent scholarship and developed an arsenal of mechanisms for taming and restructuring it. These are the Latter-Day Imperialists. The third group recognizes the outsider scholars, agreeing and disagreeing with them as they do with their inner-circle colleagues. This is the Road to Damascus group, for they have seen the light.

\section{The Unconverted}

A few from the original group of writers continue to ignore the new voices of color and the feminists. This practice leads to many of the scholarly deficiencies I noted several years ago, deficiencies extending far beyond failure to give recognition when it is due. [FN24] *1356 Van Alstyne, for example, in a recent article on the right to an abortion, [FN25] slights feminist analysis and describes the woman's interest as lacking any constitutional or moral foundation. [FN26] He frames the issue as the right to destroy third-party life, [FN27] cites mainly male authorities, [FN28] and gives short shrift to feminist commentators, mentioning but three in passing footnotes. [FN29]

Others do cite the new literature but opt for the most familiar, and perhaps safest, versions. For example, when Laurence Tribe writes of the critique of constitutional determinacy, he often refers to writers such as Mark Tushnet, ignoring the more pointed criticisms by feminists such as Catharine MacKinnon and Critical Race Theories such as Derrick Bell. [FN30] This results in a softened $* 1357$ and incomplete picture of the debate about liberalism's defects. [FN31] It results, for example, in the kind of textbook on civil rights legislation, recently updated by Theodore Eisenberg and published by Michie, where nearly every inner-circle author is cited yet among modern feminists only one grudging "see generally" cite is given to Martha Minow and a "see" cite is given to Vicky Schultz. [FN32] The $* \mathbf{1 3 5 8}$ impression that could be received from reading these otherwise impressive works is that the liberal system of law and politics that has reigned since 1930 is largely intact and that the challengers are doing little more than raising variations on a familiar theme.

\section{The Latter-Day Imperialists}

There comes a time when most scholar can no longer ignore the work being done by previously excluded writers. [FN33] Then, two possible responses exist. One is thoughtful inclusion of the previously excluded work. The other is limited, grudging, or calculated acceptance, coupled with resort to an arsenal of mechanisms to reduce its impact. The old-line, inner-circle scholars have employed three types of mechanisms to lessen the "threat" of insurgent scholarship; newcomers to the field have developed even more. [FN34]

Mechanism one: Oh Yes, Before I Forget: The Afterthought. One way to acknowledge outsider scholarship without fully assimilating it is to cite it at the end of a string citation. In the main text the author can continue to rely on the familiar list of friends and acquaintances, saving reference to critical scholarship for a footnote, frequently of the "see generally" or "see 
also" variety. [FN35] *1359 This approach allows the author to show that he is familiar with the new work, while avoiding fully accounting for it in his analysis. The approach also conveys the message that minority of feminist writing is deservedly obscure, and thus worthy only of passing mention.

Mechanism two: The Stereotypical Dismissal. An established author can dismiss a troublesome radical by caricaturing her or appealing to the reader's pre-existing assumptions about her writings without treating those writings seriously. [FN36] Alternatively, the author can merely call the new voices utopian, daring, "interesting," or not really doing law. [FN37] These approaches enable the writer to avoid confronting what the criticalist is saying. The teeth of the criticism are thus drawn, and it emerges in more innocuous form than if it had remained unmentioned.

Mechanism three: I'm So Hip. The Establishment writer cites to his familiar inner circle for $95 \%$ of his article. Then, for a proposition or section that cries out for citation to a Critical Race Theorist or feminist, the author will cite to one: Gee, aren't I hip! The author appears to be recognizing and assimilating outsider scholarship, when he is actually doing little to integrate such scholarship into his own. [FN38] For example, a scholar writing or teaching about $* \mathbf{1 3 6 0}$ developments in evidence law considers feminist thought only in connection with his treatment or rape. He writes the rest of his article or teaches the rest of his course as he has always done-linearly, hierarchically, and with little thought to its impact on women or the poor. [FN39]

\section{Those on the Road to Damascus}

Some original inner-circle authors have accepted and incorporated the writings of the Critical Race Theorists and feminists. Instead of dismissing their writings or ignoring them outright, the mainstream author engages their propositions or ideas in a forthright manner. [FN40] When an author raises an issue from outsider scholarship and takes the time to discuss his agreement or disagreement $* \mathbf{1 3 6 1}$ with it, he is recognizing its validity and relevance; it is not simply brushed aside or ignored. [FN41]

This thoughtful treatment of outsider scholarship encourages expansion of the civil rights canon, which indeed recognizes the current condition of civil rights scholarship. [FN42] In that sense, it constitutes an awareness on the part of these members of the inner circle that civil rights writing has not really been composed of two separate strains but rather of parallel traditions that must inevitably lose their Euclidean separateness and become one integrated tradition. There is nothing magical about this merging. It is a matter of scholarship as usual; relevant, important work exists, which is read, criticized, and cited. The only thing remarkable about this scholarship as usual is that, in law, in a few places, it is finally happening.

\section{THE NEW GENERATION: THE IMPERIAL SCHOLAR UPDATED}

In The Imperial Scholar I found that the bulk of writing in the areas of equality and civil rights was done by a small circle of approximately two dozen white male scholars writing in the top reviews and teaching at the top law schools. [FN43] Part I of this Article examined the later careers and output of these same scholars, finding that some scholars have continued their old ways while others have reformed. Still others have grudgingly or halfheartedly adjusted to the new writing by adopting tokenistic citation mechanisms such as The Afterthought, Stereotypical Dismissal, and I'm So Hip. [FN44]

Since I began writing The Imperial Scholar ten years ago, however, newcomers have arrived on the scene. Many of these are white; most are males; some have brought reputations achieved in other areas of the law. This Part examines these new writers and their citation practices. As with the old-line group, I find that a few of the new scholars are relatively egalitarian in their scholarship, citing Critical Race Theorists and radical feminists about as *1362 frequently as one might fairly expect. [FN45] Some new scholars, however, steadfastly rely on Frank Michelman, Owen Fiss, and other familiar stalwarts. [FN46] A third group is for my purposes the most fascinating. This group, the neo-imperialist scholars, has deployed an almost baroque variety of ways to minimize, marginalize, co-opt, soften, miss the point of, selectively ignore, or generally devalue the new insurgent writers. 
Mechanisms four and five: The hero, the zero. As with the original inner-circle scholars, the new majority-race writers have their heroes and zeroes. Duncan Kennedy, Alan Freeman, Alex Aleinikoff, and Gary Peller cite the new voices appropriately, sometimes agreeing and sometimes taking issue with them. [FN47] Other new entrants, however, either ignore the insurgent scholars or treat their work diffidently. One dynamic young, majority-race writer, for example, in a long, heavily footnoted article refers to dozens of white male writers, but collects works by women and minority authors in a single footnote, making little effort to distinguish, quote, or refer to particular passages from them. [FN48] Another author offers two "special interest" references, one for feminists and one for Critical Race Theorists. [FN49] In an article on slavery and slave law, a third entrant only once cites to Bell's Race, Racism and American Law, a standard work [FN50]-she cites Sunstein, Tushnet, Tribe, and Bickel more-and at no time mentions Leon Higginbotham's well-regarded history, In the Matter of Color. [FN51] A fourth wrote a stinging footnote chastising a number of the new-voice authors for dangerous reliance on notions of class-based harm and redress. [FN52] Unlike some, this $* 1363$ author at least cited oppositional scholars for a proposition, if only to attack it.

Mechanism six: "Yeah, yeah"; No need to tell me more. Many of the new writers in the field of civil rights cite work by women and minorities as perfunctorily as the old-timers do, [FN53] but with a difference. That difference consists of citing an early page of an article or book-for example, page three, not 403. When an author does this regularly, it raises the suspicion that he has not bothered to read the entire article or book, but has merely leafed through the article's preface or introduction in search of a general proposition he can cite with a minimum of effort. [FN54] The author discharges his obligation to refer to the new voices but avoids the hard work of reading the entire piece and dealing with it seriously. The number of references to the middle or latter pages of Catharine MacKinnon's writing on pornography is much smaller than the number of references to its opening pages, a treatment some other radical feminists receive as well. [FN55] Women will recognize this treatment as a conversational gambit many men use-interruption. The male listens to a woman's opening words, then bursts in to finish her sentence, saying "Yeah, yeah. I get it; no need to go on ... now, what do you think about my idea?" [FN56] Derrick Bell also garners references of this sort. [FN57]

*1364 Mechanism seven: "I know": The facile (and safe) translation. This mechanism translates a novel, hard-edged, and discomfiting thesis by an outside writer so that it becomes familiar, safe, and tame. Often the translation forces the thesis into liberal-legalist terms that were intended to be avoided. For example, some scholars translate MacKinnon's work on pornography into an intriguing First Amendment question. [FN58] MacKinnon does not consider pornography a First Amendment question, but a near-crime, a civil rights offense against women. [FN59] Once translated into a First Amendment framework her proposal loses much of its urgency and original character. [FN60]

Mechanism eight: "I loved Dan's idea." A number of the new writers show familiarity with ideas feminists and Critical Race Theory scholars have been proposing, but either forget where they $* 1365$ heard them, [FN61] or cite a derivative source-a critic, or a majority-race commentator-to summarize outsider views. For example, some scholars rely on Randall Kennedy, a critic of Critical Race Theory, for a summary of Critical Race Theory positions, ; [FN62] others cite men such as Cass Sunstein for radical feminist views developed by Catharine MacKinnon and others. [FN63] One writer cited Deborah Rhode for "reasoning from the bottom," [FN64] a view associated at least as much with Mari Matsuda. [FN65]

This approach corresponds to another experience familiar to most women: co-optation. A woman proposes an idea; no one in the group reacts. Twenty minutes later, a male restates and puts forward the same suggestion, which immediately wins widespread praise and thereafter becomes "Dan's idea." [FN66]

Mechanism nine: "I know just how you must have felt": Co-optation of others' experience. Some of the new writers, and a few of the original ones, make an effort to identify with the stories and accounts the outsider narrativists are offering, but in a way that co-opts or minimizes these stories. [FN67] The majority-race author draws a parallel between something in the experience of the outsider author and something that happened to him. [FN68] There is nothing $* 1366$ wrong with using analogies and metaphors to deal with the experience of others for that is how we extend our sympathies. If, however, we analogize to refocus a conservation 
or an article towards ourselves exclusively, something is wrong, especially if the experience to which we liken another's is manifestly less serious. For example, the author of one article on campus racial harassment observes that everyone experiences "insulting" or "upsetting" speech at one time or another, so what is so special about the racist version? [FN69]

Mechanism ten: "Pure poetry": How poignant, touching, or moving-Placing outsider writing on a pedestal. Some writers of majority race praise the new writing for its passionate or emotional quality. The writing is so personal, so colorful, so poetic, so "moving." [FN70] This approach can marginalize outsider writing by placing it in a category of its own. Women and minority writers feel more deeply than we; they have "soul." [FN71] The writing is evaluated as a journal of the author's individual thoughts and feelings, not as an article that delivers uncomfortable insights and truths about society and injustice. [FN72]

*1367 Mechanism eleven: Assimilation/co-optation-"We have been saying this all along." This mechanism dismisses the feminists and Critical Race Theorists as saying little new; we have been making the same points about brotherhood, equality, and civility for hundreds, if not thousands, of years. Plato, Aquinas, Austin, Unger, and any favorite male author urged that society be arranged justly and that all should be treated with respect. [FN73] On some level, every truth is foreshadowed by or include in every other. Yet one might argue that earlier authorities wrote inadequately and spoke poorly to our condition because that condition persists today. If outsider voices are addressing new or old grievances in new ways, one ought not dismiss what they are saying merely because someone else previously said something remotely similar. [FN74]

Mechanism twelve: "She wrote just one" (And I'll cite it, too). Some of the mainstream authors treat the new voices as though each of them had written exactly one article or book. [FN75] Susan Estrich is $\boldsymbol{*} \mathbf{1 3 6 8}$ cited for her book on rape, [FN76] Mari Matsuda for Looking to the Bottom, [FN77] Derrick Bell for and We Are Not Saved, [FN78] me for The Imperial Scholar. [FN79] Each of these writers has written many works, arguably of comparable merit to the one cited. [FN80] Routinized, stereotypical citation to one work gives the impression the author wrote only the one. It also conveys the message that insurgent writers can only write one work, probably an anomaly, the result of a gigantic effort or internal convulsion that they are capable of producing only once in a lifetime. [FN81]

Mechanism thirteen: The all-purpose citation. The author has a flash of insight, into the way constitutional equality works, for example. Midway through the article it dawns on the author that he had better cite a minority. What better place to do so than for the proposition that (1) racism is terrible, (2) discrimination still exists, or (3) we all must work really hard at dealing with it. Most authors of color surely say these things somewhere, so the author chooses onehow about Crenshaw? [FN82]

\section{III. "AT THE MARGIN": WHY WE ALWAYS FAIL TO RECOGNIZE NEW STORIES}

Even though the new voices are finding their way into the pages of the top reviews and journals, they are not being quickly and easily integrated into the conversations and dialogues of traditional legal scholarship. Some of the resistance may be intentional and mean-spiritedwhy should I cite that outsider, after the nasty things she said about me or my friends? [FN83] Resistance may also be the $* \mathbf{1 3 6 9}$ product of inflexibility and an unwillingness to entertain new positions-I'm forty-five years old; why do I have to read all these new authors anyway? [FN84]

But most mainstream legal writers are neither mean-spirited nor lazy. I think the most likely explanation for most of the mechanisms I have detailed lies elsewhere. Legal scholarship is currently radically transforming itself. [FN85] Formalism and case-crunching notes and articles running 100 pages or more, littered with hundreds of footnotes, are passing into history. [FN86] Even legal process and interdisciplinary "law and" scholarship have lost much of their momentum. In their places a subtler yet audacious form of legal writing has appeared, with roots in postmodernism, critical thought, and narrative theory. [FN87] The authors, format, and authorities cited are radically different from those that came before. If not a full-fledged paradigm shift, something similar seems to be happening. As sociologists of knowledge have pointed out, such shifts are at first resisted by those steeped in the old regime; the paradigm changes only when the costs of resisting it become unacceptable compared to the gains of 
adopting the new one. [FN88] $* 1370$ Resistance to the new voices, then, may be as natural as that which the Langdellians and "mechanical jurisprudes" raised to legal realism early in this century. All change is costly. What more natural reaction than postponing dealing with it as long as possible? [FN89]

A second, related explanation applies insights from narrative theory. [FN90] As many have pointed out, reality comes to us not as a given but in terms of narratives, mindsets, or storiesinterpretive structures by which we construct and come to terms with the world of reality. [FN91] Each of us is the product of a large number of such understanding, or "stories," by which we reduce the diversity of daily life to manageable proportions. In a sense, we are our stock of stories and they us. [FN92]

When a feminist or Critical Race Theorist offers a radically new story, we evaluate it in terms of the one we currently hold. If it seems too different, we are apt to reject it as extreme, coercive, political, harsh, or untrue. [FN93] Imagine, for example, the reaction of most liberal law students on hearing Derrick Bell's interest-convergence hypothesis for the first time. [FN94] The first response to Bell's hypothesis is re-interpretation-softening or qualifying it $* \mathbf{1 3 7 1}$ because Bell could not have intended to interpret the search for racial justice in such a scathing way. Yet for many radical race reformers, the hypothesis seems commonplace and true.

Both mechanisms lead to a melancholy truth. We postpone confronting novelty and change until they acquire enough momentum that we are swept forward. We take seriously new social thought only after hearing it so often that its tenets and themes begin to seem familiar, inevitable, and true. [FN95] We then adopt the new paradigm, and the process repeats itself. We escape from one mental and intellectual prison only into a larger slightly more expansive one. Each jail-break is seen as illegitimate. We reject new thought until, eventually, its hard edges soften, its suggestions seem tame and manageable, and its proponents are "elder statespersons," to be feared no longer. [FN96] By then, of course, the new thought has lost its radically transformative character. We reject the medicine that could save us until, essentially, it is too late. [FN97]

\section{*1372 CONCLUSION}

Nearly ten years ago in The Imperial Scholar I wrote of an inner circle of white-male scholars who systematically excluded minority voices from the central arenas of civil rights scholarship. Almost a decade later many of the actors have changed, but the situation is not greatly different. With a few notable exceptions both the original group and the newcomers rely on a panoply of devices, ranging from the dismissive Afterthought to the wishful Translation, to muffle and tame the new voices.

Thus, although critical, feminist, and minority writers are increasingly appearing in the pages of our top journals, they are still not being integrated fully or easily into the colloquies, exchanges, and dialogues of legal scholarship. Some of the resistance may be intentional, but I believe most of it results from quite ordinary forces: preference for the familiar, discomfort with impending change, and a near-universal disdain for an account or "story" that deviates too much from one upon which we have been relying to construct and order our social world.

Cultural momentum tends to be preserved. All discourse marginalizes. We resist transformative thought until it has lost the power to transform us. If I am right, imperial scholarship will continue to be with us a long time.

[FNd1]. Charles Inglis Thomson Professor of Law, University of Colorado School of Law; J.D. 1974, University of California School of Law (Boalt Hall). I gratefully acknowledge the suggestions and assistance of Kelly Robinson, Pierre Schlag, Erich Schwiesow, and Jean Stefancic in writing this Article.

[FN1]. Richard Delgado, The Imperial Scholar: Reflections on a Review of Civil Rights Literature, 132 U.PA.L.REV. 561 (1984) [hereinafter The Imperial Scholar]. For a recent article in a similar vein, see Patricia A. Cain, Feminist Legal Scholarship, 77 IOWA L.REV. (forthcoming 1992).

[FN2]. Jon Wiener, Law Profs Fight the Power, 249 NATION 246, 246 (1989) (quoting Derrick Bell). 
[FN3]. See The Imperial Scholar, supra note 1, at 562 n.3 (listing the 26 most-cited authors and their representative works).

[FN4]. See id. at 563 ("Paul Brest cites Laurence Tribe. Laurence Tribe cites Paul Brest and Owen Fiss. Owen Fiss cites Bruce Ackerman, who cites Paul Brest and Frank Michelman, who cites Owen Fiss and Laurence Tribe and Kenneth Karst . . ..").

[FN5]. See id. at 567 (listing lack of information, decreased or misdirected passion, differing agendas, incomplete commitment to remedies, unconscious perpetuation of stereotypes, and continued dependency as reasons why minority scholarship or minority rights cannot be ignored).

[FN6]. See id. at 573-78.

[FN7]. See id. at 577.

[FN8]. An example is the assertion that perspective matters-who is writing may be as important as what is written. See, e.g., Symposium, Excluded Voices: Realities in Law and Law Reform, 42 U. MIAMI L.REV. 1, 1 (1987) (describing the symposium as being "about how differences in opinions, motivations, and language can construct social and political ideas that may form the basis for law reform"); Symposium, Legal Storytelling, 87 MICH.L.REV. 2073 (1989) (containing articles by Milner S. Ball, Derrick Bell, Richard Delgado, Mari J. Matsuda, Patricia Williams, and Steven L. Winter on the place of voice and perspective in legal scholarship). But see Stephen L. Carter, Academic Tenure and "White Male" Standards: Some Lessons from the Patent Law, 100 YALE L.J. 2065, 2067 (1991) (disagreeing with the view that the identity of the author is relevant to considering the scholarship produced).

[FN9]. See, e.g., Derrick A. Bell, Jr., Bakke, Minority Admissions, and the Usual Price of Racial Remedies, 67 CAL.L.REV. 3, 4 (1979) (comparing the exclusion of minorities from civil rights scholarship to parents who tell their children: "Keep quiet. We are talking about you, not to you.").

[FN10]. See infra note 15.

[FN11]. See, e.g., Randall L. Kennedy, Racial Critiques of Legal Academia, 102 HARV.L.REV. 1745 (1989) (commending Critical Race Theorists for their intellectual contributions to academia by taking issue with the manner in which they present their arguments).

[FN12]. For coverage of Critical Race Theorists, see Charles Rothfeld, Minority Critic Stirs Debate on Minority Writing, N.Y. TIMES, Jan. 5, 1990, at B9 (describing the controversy created by Randall Kennedy's critique of critical race studies); Wiener, supra note 2. For an example of coverage of radical feminism, see Fred Strebeigh, Defining Law on the Feminist Frontier, N.Y. TIMES, Oct. 6, 1991, § 6 (Magazine), at 29 (describing the work of Catharine A. MacKinnon).

[FN13]. They certainly could have been; the reader, however, having become consciously aware of these mechanisms, will be able to find them on her own all too easily.

[FN14]. See The Imperial Scholar, supra note 1, at 562 n.3 (studying the citation practices of Bruce A. Ackerman, Alexander M. Bickel, Boris I. Bittker, Charles L. Black, Jr., Vincent Blasi, Paul Brest, Archibald Cox, Theodore Eisenberg, John H. Ely, Owen M. Fiss, Lino A. Graglia, Kent Greenawalt, Gerald Gunther, William E. Hellerstein, Louis Henkin, Harold W. Horowitz, John Kaplan, Kenneth L. Karst, Frank I. Michelman, Robert M. O'Neil, Louis H. Pollak, Terrance Sandalow, Theodore J. St. Antoine, Laurence Tribe, William Van Alstyne, and Herbert Wechsler). New entrants not considered in The Imperial Scholar will be examined later; their work represents some of the most interesting and subtle ways of marginalizing outsider scholarship. 
See infra Part II.

[FN15]. Outsiders currently have a substantial presence in "elite" law reviews. Of the articles on civil rights published in three top journals, the Harvard Law Review, the Yale Law Journal, and the University of Pennsylvania Law Review, between 1985 and 1990, nearly three-fourths were written by women or people of color. See, e.g., Robin D. Barnes, Race Consciousness: The Thematic Content of Racial Distinctiveness in Critical Race Scholarship, 103 HARV.L.REV. 1864 (1990); Derrick Bell, The Supreme Court 1984 Term, Foreword: The Civil Rights Chronicles, 99 HARV.L.REV. 4 (1985); Derrick Bell \& Preeta Bansal, The Republican Revival and Racial Politics, 97 YALE L.J. 1609 (1988); Scott Brewer, Introduction: Choosing Sides in the Racial, Critiques Debate, 103 HARV.L.REV. 1844 (1990); Lea Brilmayer, Carolene, Conflicts, and the Fate of the "Inside-Outsider," 134 U.PA.L.REV. 1291 (1986); Stephen L. Carter, When Victims Happen to be Black, 97 YALE L.J. 420 (1988); Kimberle W. Crenshaw, Race, Reform, and Retrenchment: Transformation and Legitimation in Antidiscrimination Law, 101 HARV.L.REV. 1331 (1988); Drew S. Days, III, Fullilove, 96 YALE L.J. 453 (1987); Richard Delgado, Derrick Bell and the Ideology of Racial Reform: Will We Ever Be Saved?, 97 YALE L.J. 923 (1988); Richard Delgado, Mindset and Metaphor, 103 HARV.L.REV. 1872 (1990); Leslie G. Espinoza, Masks and Other Disguises: Exposing Legal Academia, 103 HARV.L.REV. 1878 (1990); Susan R. Estrich \& Kathleen M. Sullivan, Abortion Politics: Writing for an Audience of One, 138 U.PA.L.REV. 119 (1989); A. Leon Higginbotham, Jr., The Life of the Law: Values, Commitment, and Craftsmanship, 100 HARV.L.REV. 795 (1987); Randall Kennedy, A Reply to Philip Elman, 100 HARV.L.REV. 1938 (1987); Randall Kennedy, Martin Luther King's Constitution: A Legal History of the Montgomery Bus Boycott, 98 YALE L.J. 999 (1989); Randall L. Kennedy, McClesky V. Kemp: Race, Capital Punishment, and the Supreme Court, 101 HARV.L.REV. 1388 (1988); Randall Kennedy, Persuasion and Distrust: A Comment on the Affirmative Action Debate, 99 HARV.L.REV. 1327 (1986); Vicki Schultz, Telling Stories About Women and Work: Judicial Interpretations of Sex Segregation in the Workplace in Title VII Cases Raising the Lack of Interest Argument, 103 HARV.L.REV. 1750 (1990); Kathleen M. Sullivan, Sins of Discrimination: Last Term's Affirmative Action Cases, 100 HARV.L.REV. 78 (1986); Kathleen M. Sullivan, Unconstitutional Conditions, 102 HARV.L.REV. 1415 (1989); Lea S. VanderVelde, The Labor Vision of the Thirteenth Amendment, 138 U.PA.L.REV. 437 (1989); Robin West, Law, Rights, and Other Totemic Illusions: Legal Liberalism and Freud's Theory of the Rule of Law, 134 U.PA.L.REV. 817 (1986).

The list above includes articles published by minorities and women (on the subjects in question) in only three of the top law reviews. Their entire output is, of course, much larger. THE ASSOCIATION OF AMERICAN LAW SCHOOLS, AALS DIRECTORY OF LAW TEACHERS 199091 (1990) [hereinafter AALS DIRECTORY] lists 610 minority law professors. See id. at 1127-30. Although no precise figures exist, I estimate that at least half are teaching or writing in the areas of constitutional law or minority rights. The number of women in legal academia is much larger-currently about $23 \%$ of the law professoriate. See Telephone Interview with Kathy Grove, American Bar Association (Nov. 25, 1991); see also Paul M. George \& Susan McGlamery, Women and Legal Scholarship: A Bibliography, 77 IOWA L.REV. (forthcoming 1992) (listing feminist legal works).

[FN16]. See supra note 15 (noting that women and people of color wrote nearly three-fourths of civil rights scholarship appearing in the Harvard Law Review, Yale Law Journal, and University of Pennsylvania Law Review from 1985 to 1990).

[FN17]. Western Addition Community Org. v. NLRB, 485 F.2d 917, 940 (D.C. Cir.1973) (Wyzanski, J., dissenting), rev'd sub nom. Emporium Capwell Co. v. Western Addition Co., 420 U.S. 50 (1975), quoted in The Imperial Scholar, supra note 1, at 577-78. On the show's death, at least in a numerical sense, see supra note 15.

[FN18]. According to the latest AALS Directory, of the original 26, Bittker, Black, Cox, Henkin, Pollak, and Wechsler have retired or left full-time teaching; Brest, Blasi, and Horowitz are administrators; and Bickel is dead. See AALS DIRECTORY, supra note 15. 
[FN19]. See, e.g., Charles L. Black, Jr., My World with Louis Armstrong, 95 YALE L.J. 1595 (1986) (discussing personal reflections on race discrimination in the South); Charles L. Black, Jr., Reflections on Teaching and Working in Constitutional Law, 66 OR.L.REV. 1 (1987) (commenting on human rights, the Constitution, and the powers of the presidency); Robert M. O'Neil, Preferential Admissions Revisited: Some Reflection on DeFunis and Bakke, 14 J.C. \& U.L. 423 (1987) (discussing the history of and legal approaches to preferential admissions).

[FN20]. Compare Archibald Cox, The Supreme Court, 1965 Term-Foreword: Constitutional Adjudication and the Promotion of Human Rights, 80 HARV.L.REV. 91 (1966) (discussing the need for judicial activism in protection of minorities' interests) with Archibald Cox, The Role of the Supreme Court: Judicial Activism or Self Restraint?, 47 MD.L.REV. 118 (1987) (same, but emphasizing institutional roles and concerns); compare also John $\mathrm{H}$. Ely, The Constitutionality of Reverse Racial Discrimination, 41 U. CHI.L.REV. 723 (1974) (offering theory to justify affirmative action) with John H. Ely, Another Such Victory: Constitutional Theory and Practice in a World Where Courts Are No Different from Legislatures, 77 VA.L.REV. 833 (1991) (discussing institutional limitations on federal judges' activism).

[FN21]. See supra note 20 (comparing Cox's and Ely's shifts in scholarship over time). The works of Bruce Ackerman, Vincent Blasi, Owen Fiss, Gerald Gunther, and Terrance Sandalow also illustrate this shift. The LegalTrac database shows Blasi publishing eight articles since 1984, all on constitutional law subjects or federalism; none deal expressly with the rights of women or minorities. For Ackerman the figures are nine (other subjects), one (rights of minorities); for Fiss, 16 (other subjects), one (rights of minorities); for Gunther, 11 (other subjects), one (rights of minorities); for Sandalow, 11 (other subjects), one (rights of minorities).

[FN22]. For example, political theory and legal culture are two areas to which Ackerman and Ely have addressed their formidable talents. See, e.g., 1 BRUCE ACKERMAN, WE THE PEOPLE: FOUNDATIONS (1991); JOHN H. ELY, DEMOCRACY AND DISTRUST (1980).

[FN23]. See, e.g., Trafficante v. Metropolitan Life Ins. Co., 409 U.S. 205 (1972) (granting tenants who alleged they lost the benefits of living in an integrated community standing to sue for race discrimination under Title VIII regardless of their color); City of Richmond v. J.A. Croson Co., 488 U.S. 469 (1989) (disallowing minority set-asides unless the city has previously discriminated against the minority group, which implicitly recognizes the "innocent whites" argument against affirmative action).

[FN24]. See The Imperial Scholar, supra note 1, at 567-73 (detailing distortions, skewings, and omissions in the civil rights literature).

[FN25]. See William Van Alstyne, Closing the Circle of Constitutional Review from Griswold v. Connecticut to Roe v. Wade: An Outline of a Decision Merely Overruling Roe, 1989 DUKE L.J. 1677.

[FN26]. See id. at 1679-80 (describing the right recognized in Roe v. Wade, 410 U.S. 113 (1973), as a right "to destroy third-party life that one's own acts . . . had brought about," and claiming that such a right could "gain no constitutional purchase" irrespective of how it was described).

[FN27]. See id. at 1680-82, 1685, 1688.

[FN28]. See id. at 1677 n.1, 1681 n.15.

[FN29]. See id. at 1677 n.1 (referring to Estrich \& Sullivan, supra note 15, as a "strong followon article" to Walter Dellinger \& Gene B. Sperling, Abortion and the Supreme Court: The Retreat from Roe v. Wade, 138 U.PA.L.REV. 83 (1989), the article that prompted Van Alstyne's own 
writing); id. at 1685 n.30 (citing Fran Olsen, Unraveling Compromise, 103 HARV.L.REV. 105, 117-26 (1989), as additional support for the proposition that men favor legalized abortion more than women); id. at 1687 n.38 (citing Judith Thompson, A Defense of Abortion, 1 PHIL. \& PUB. AFF. 47 (1971), for the existence of arguments based on the Thirteenth Amendment's prohibition on involuntary servitude, but declaring such arguments irrelevant to pregnancies resulting from consensual intercourse).

[FN30]. See LAURENCE H. TRIBE, AMERICAN CONSTITUTIONAL LAW 13 n.9 (2d ed. 1988) (citing only Mark V. Tushnet, A Note on the Revival of Textualism in Constitutional Theory, $58 \mathrm{~S}$. CAL.L.REV. 683, 685 (1985), for the idea of constitutional indeterminacy); Laurence H. Tribe, On Reading the Constitution, 1988 UTAH L.REV. 747, 762, 770 (citing Mark V. Tushnet, Diatribe, 78 MICH.L.REV. 694 (1980), and Mark V. Tushnet, The Dilemmas of Liberal Constitutionalism, 42 OHIO ST. L.J. 411 (1981), for same).

Several sections of Tribe's American Constitutional Law that call for citation to a critical minority or radical feminist writer are notably devoid of them. Tribe's treatment of Brown v. Board of Education, 347 U.S. 483 (1954), includes no reference to his colleague Derrick Bell's path-breaking article, Brown v. Board of Education and the Interest-Convergence Dilemma, 93 HARV.L.REV. 518, 523-26 (1980), in which Bell argues that Brown was decided not so much as a matter of conscience by the white establishment, but rather to forward economic and Cold War imperatives important to our ruling elite. See TRIBE, supra, at 1475-80, 1488-90, 1499, 1514. Tribe's section on pornography and feminism mentions only Catharine MacKinnon and Susan Estrich among legal feminists; Cass Sunstein (a man) is cited more often. See id. at 92028. Neither the idea that the Constitution was an anti-black instrument, an idea put forward by Bell and Thurgood Marshall among others, nor the thesis by Olsen, MacKinnon, and others, that the law is inherently anti-female, is mentioned.

This treatment stands in marked contrast to those who argue that racism affects our entire political and legal systems, and hence anti-racist thought and commentary should be brought into every area of constitutional discussion, not just equal protection. See T. Alexander Aleinikoff, The Constitution in Context, 63 COLO.L.REV. (forthcoming 1992); Stephen Feldman, Whose Common Good? Racism in the Political Community, 80 GEO. L.J. (forthcoming 1992). To the extent these observations are valid, Tribe's omissions become glaring. As evidence, consider that American Constitutional Law contains no index entries for legitimation, Critical Race Theory, patriarchy, hierarchy, hegemony, indeterminacy, or deconstruction. Gramsci, Foucault, Habermas, Marcuse, and Marx are not mentioned at all.

[FN31]. Derrick Bell, for example, argues that our system of anti-discrimination laws and rules is not only manipulable and prone to backsliding but also designed to operate that way. See DERRICK A. BELL, AND WE ARE NOT SAVED (1987). Catharine MacKinnon argues that the legal system is inherently biased against women and that applying sex-neutral and race-neutral concepts of fairness and equal protection will only exacerbate the law's biases. See CATHARINE MACKINNON, FEMINISM UNMODIFIED: DISCOURSES ON LIFE AND LAW 104-05, 164-66 (1987); CATHARINE MACKINNON, TOWARD A FEMINIST THEORY OF THE STATE 163 (1989). These sources would have more vividly conveyed to Tribe's readers the growing disenchantment among outsider writers with formalism in constitutional thought. For recent treatment of liberalism's defects, see THE POLITICS OF LAW: A PROGRESSIVE CRITIQUE (David Kairys ed., 2d ed. 1990) [hereinafter POLITICS OF LAW]; Symposium, The Critique of Normativity, 139 U.PA.L.REV. 801 (1991); see also Richard Delgado, Enormous Anomaly? Left-Right Parallels in Recent Writing About Race, 91 COLUM.L.REV. 1547-60 (1991) (book review) (discussing four recent books and their criticism of liberalism).

[FN32]. See THEODORE EISENBERG, CIVIL RIGHTS LEGISLATION 924, 1207 (3d ed. 1991) (citing Martha Minow, Learning to Live with the Dilemma of Difference: Bilingual and Special Education, LAW \& CONTEMP. PROBS., Spring 1985, at 157, and Vicky Schultz, Telling Stories About Women and Work: Judicial Interpretations of Sex Segregation In the Workplace in Title VII Cases Raising the Lack of Interest Argument, 103 HARV.L.REV. 1749 (1990)). The 1700page casebook contains hundreds of references to works by white men, including several by the 
author himself. But the section on sexual harassment of women in the workplace lacks any reference to MacKinnon's groundbreaking work, CATHARINE MACKINNON, SEXUAL

HARASSMENT OF WORKING WOMEN: A CASE OF SEX DISCRIMINATION (1979). See

EISENBERG, supra, at 893-900. Additionally, the sole treatment of discrimination against

Mexican-Americans is an excerpt from a relatively old article by two white men, Gary A.

Greenfield \& Don B. Kates, Jr., Mexican Americans, Racial Discrimination, and the Civil Rights

Act of 1866, 63 CAL.L.REV. 662 (1975). See EISENBERG, supra, at 104. Eisenberg overlooked work by authors such as Olivas, Palacios, Lopez, Reynoso, and Torres, none of whom are cited anywhere in the book. For examples of these authors' work, see MICHAEL A. OLIVAS, THE DILEMMA OF ACCESS: MINORITIES IN TWO YEAR COLLEGES (1979); Richard Delgado \& Vicky Palacios, Mexican-Americans As a Legally Cognizable Class under Rule 23 and the Equal Protection Clause, 50 NOTRE DAME L.REV. 393 (1974); Gerald P. Lopez, The Idea of a Constitution in the Chicano Tradition, 37 J. LEGAL EDUC. 162 (1987); Leo M. Romero et al., The Legal Education of Chicano Students: A Study in Mutual Accomodation and Cultural Conflict, 5 N.M.L.REV. 177 (1975); Gerald Torres, Local Knowledge, Local Color: Critical Legal Studies and the Law of Race Relation, 25 SAN DIEGO L.REV. 1043 (1988). Critical Race Theorists, such as Mari Matsuda and Patricia Williams, are conspicuously absent, and the main excerpt on sex discrimination and Title VII is an article written by a white man. See EISENBERG, supra, at 86371 (excerpting Richard A. Wasserstrom, Racism, Sexism, and Preferential Treatment: An Approach to the Topics, 24 UCLA L.REV. 581 (1977)). The only African-American author whose name I recognize is Drew Days. See EISENBERG, supra, at 764 n. 10 (citing Days, supra note 15).

[FN33]. This time seems to have arrived in civil rights scholarship. See supra note 15.

[FN34]. I discuss the latters' response infra Part II. Joanna Russ found a similar tendency to rely on a few recurring mechanisms for suppressing insurgent writing. Her classic, JOANNA RUSS, HOW TO SUPPRESS WOMEN'S WRITING (1983), examines the techniques literacy scholars have used throughout the 19th and 20th centuries to belittle literature by women.

[FN35]. See. e.g., Bruce Ackerman, Constitutional Politics/Constitutional Law, 99 YALE L.J. 453, 466 n.23 (1989). In the main text Ackerman uses Owen Fiss as an example of a collectivist who stresses the rights of disadvantaged groups to equal treatment. But in his footnote to Owen Fiss, Ackerman mentions that Catharine MacKinnon has "more recently developed and deepened this group-oriented perspective in SEXUAL HARASSMENT OF WORKING WOMEN (1979), and TOWARD A FEMINIST THEORY OF THE STATE (1989)." Id. Why, then, is Mackinnon not in the main text in place of or along with Owen Fiss? Patricia Cain argues that citation to feminists is absent, dismissive, or trivializing. See Cain, supra note 1.

[FN36]. See, e.g., Boris I. Bittker, The Bicentennial of the Jurisprudence of Original Intent: The Recent Past, 77 CAL.L.REV. 235, 257 (1989) (dismissing Unger by making light of his "CLS shock troops," who began to preach original intent when they discovered the Declaration of Independence, causing conservatives to leave by the rear door after first pronouncing themselves "Original Original Intentionists"); Paul D. Carrington, Of Law and the River, $34 \mathrm{~J}$. LEGAL EDUC. 222, 227 (1984) (stating that Critical Legal Studies writers are preaching anti-law and that to be consistent with their own premises, they should leave the academy); Lino A. Graglia, Permissible and Impermissible, Content-Based Restrictions on Freedom of Speech, 10 HARV. J.L. \& PUB. POL'Y 67, 71-72 (1987) (arguing that MacKinnon's work is little more than feminist propaganda and that its adoption by two cities is "the best argument against democracy I have heard in some time").

[FN37]. See, e.g., Carrington, supra note 36 (stating that CLS writers are impassioned and audacious but not really doing law, are poor influences on their students, and should consider transferring to other university departments); see also infra notes 70-72 and accompanying text (discussing marginalizing writing by placing outsider writing in a category of its own). 
[FN38]. See, e.g., Paul Brest, Affirmative Action and the Constitution: Three Theories, 72 IOWA L.REV. 281, 281 n.2 (1987) (citing no minority scholar or woman and only one criticalist, Alan Freeman, in an article about a racially-based and gender-based policy). Although Alan Freeman advanced and documented the astonishing proposition that Supreme Court anti-discrimination law negatively affects persons of color, see Alan D. Freeman, Legitimizing Racial Discrimination Through Antidiscrimination Law: A Critical Review of Supreme Court Doctrine, 62 MINN.L.REV. 1049, 1052-119 (1978), Brest cites Freeman for the obscure proposition that "fault" theories of racial justice are in question. See Brest, supra, at 281 n.2. In Brest's discussion of theories justifying affirmative action, he does not cite writers of color, such as Bell, who have expressed grave misgivings over the doctrine, its footing, and its intentions, see BELL, supra note 31 , at 146-61.

Even conscientious authors such as Frank Michelman are occasionally guilty of dropping the isolated, fashionable citation. See Frank Michelman, Law's Republic, 97 YALE L.J. 1493, 1496 n.10 (1988). In an early footnote he cites some of the Critical Race Theorists and feminists to illustrate the problems of exclusion and the stigma of "otherness"; he does not, however, cite to any of them for their equally important works on what to do about the problem of white race consciousness. For examples of these works see BELL, supra note 31 (explaining the alternatives of litigation, emigration, disruption, moral appeals and exhortation, self-help, and partisan politics); Barnes, supra note 15, at 1869-70 (defending the need for Critical Race scholars to search for truth by speaking from other experiences in response to the traditional white-male, Judeo-Christian centered perspective). The remainder of the article does not consider these writers again, except for a brief cite to MacKinnon on pornography and on Roe $v$. Wade, see Michelman, supra, at 1532 n.161, 1534 n.170.

Robert O'Neil, an author who earlier conceded that I had a point about imperial scholarship, see Robert M. O'Neil, A Reaction to the Imperial Scholar and Professor Delgado's Proposed Solution, 3 L. \& INEQ. J. 255 (1985), cites no minority and only two women in his piece on Bakke and DeFunis. See O'Neil, supra note 19. Like Brest, O'Neil ignores the many scholars of color who have written in this area, preferring to cite ancient articles and books by himself, Gellhorn, Epstein, and other white men. See id. at 423-30 nn.2-22.

[FN39]. See MCCORMICK ON EVIDENCE 83 n.92 (Edward W. Cleary ed., 3d ed. Supp.1987) (citing article by Massaro on rape trauma syndrome; otherwise, feminists are not much in evidence); see also supra note 31 (demonstrating tokenistic citation practices); infra notes 6874 and accompanying text (same).

[FN40]. See, e.g., Kenneth L. Karst, Boundaries and Reasons: Freedom of Expressions and the Subordination of Groups, 1990 U.ILL.L.REV. 95, 114 n. 73 (citing Derrick Bell, Kimberle Crenshaw, and Charles Lawrence as authority for various propositions having to do with the continuing menace of racism.).

[FN41]. See, e.g., id. at 114 (agreeing with outsiders that racism still exists and is a current issue); Alan Freeman, Racism, Rights and the Quest for Equality of Opportunity: A Critical Legal Essay, 23 HARV. C.R.-C.L.L.REV. 295, 331 \& n.94 (1988) (mentioning Mari Matsuda in the main text of his article and also detailing in the footnote why he disagrees with her proposition that real experiences cannot be paradoxical).

[FN42]. See supra notes 10-12, 15 and accompanying text (stating that legal scholarship is diversifying and that the canon is expanding to include new voices and approaches).

[FN43]. See The Imperial Scholar, supra note 1, at 562 n.3.

[FN44]. See supra Part I.B.2.

[FN45]. See infra note 47 and accompanying text (describing "heroes" among the new writers).

[FN46]. See The Imperial Scholar, supra note 1, at 562 n.3 (describing the original in-group). 
[FN47]. See, e.g., Aleinikoff, supra note 30 (citing numerous new-voice authors); Freeman, supra note 41 (same); Duncan Kennedy, A Cultural Pluralist Case for Affirmative Action in Legal Academia, 1990 DUKE L.J. 705 (same); Gary Peller, Race Consciousness, 1990 DUKE L.J. 758 (same); see also Cain, supra note 1 (listing Sunstein, Tobias, Chused, Karst, Michelman, and Posner as men who have taken women's writing seriously).

[FN48]. See Edward L. Rubin, The Concept of Law and the New Public Law Scholarship, 89 MICH.L.REV. 792, 811 n.55 (1991). Randall Kennedy criticized Rubin for ignoring Critical Race Theory in an earlier article. See Kennedy, supra note 11 , at 1748 n.18.

[FN49]. See J.M. Balkin, Ideology as Constraint, 43 STAN.L.REV. 1133, 1148 n.59, 1149 nn.61-

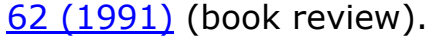

[FN50]. See VanderVelde, supra note 15, at 497 n.267.

[FN51]. See A. LEON HIGGINBOTHAM, JR., IN THE MATTER OF COLOR: RACE AND THE AMERICAN LEGAL PROCESS: THE COLONIAL PERIOD (1978).

[FN52]. See David Rosenberg, Class Actions for Mass Torts: Doing Individual Justice by Collective Means, 62 IND. L.J. 561, 562 n.5 (1987).

[FN53]. See supra text accompanying note 35 (describing Mechanism one: The Afterthought).

[FN54]. For examples of such early-page citation, see Neal Devins, Gender Justice and Its Critics, 76 CAL.L.REV. 1377, 1382 n.27, 1385 n.36, 1389 n.62, 1390 nn.63 \& 65 (1988) (book review) (citing to early passages of MacKinnon's and Minow's works); Suzanna Sherry, An Essay Concerning Toleration, 71 MINN.L.REV. 963, 988 n.113 (1987) (mentioning MacKinnon's work on pornography legislation but not bothering to cite it); id. at $988 \mathrm{n} .114$ (providing full citation to a male author on pornography).

[FN55]. See, e.g., Edward Rubin, Television and the Experience of Citizenship, 68 TEX.L.REV. 1155,1155 n.3 (1990) (citing to early pages of MacKinnon's works); Suzanna Sherry, Civic Virtue and the Feminine Voice in Constitutional Adjudication, 72 VA.L.REV 543, 565 n.98, 586 n.182 (1986) (citing to Fran Olsen's work in its entirety or to its early pages); Cass R. Sunstein, Sexual Orientation and the Constitution: A Note on the Relationship Between Due Process and Equal Protection, 55 U. CHI.L.REV. 1161, 1175 n.73 (1988) (citing male authors to particular pages and female authors to entire chapters or works).

[FN56]. See, e.g., DEBORAH TANNEN, YOU JUST DON'T UNDERSTAND: WOMEN AND MEN IN CONVERSATION 188-216 (1990) (detailing the use and the perception of interruption by men and women).

[FN57]. See, e.g., Randolph D. Moss, Participation and Department of Justice School Desegregation Consent Decrees, 95 YALE L.J. 1811, 1827 n.83 (1986) (citing to Bell's entire work). This is also an example of the "I'm So Hip" mechanism. See supra notes 38-39 and accompanying text. Moss cites Fiss, Tribe Eisenberg, and Michelman extensively about the role of the executive branch in the structural reform of desegregation law, the participation of those involved in determining desegregation procedures, and the weakness of individuals as opposed to powerful institutions such as school systems. Meanwhile, Derrick A. Bell Jr., Serving Two Masters: Integration Ideals and Client Interests in School Desegregation Litigation, 85 YALE L.J. 470 (1976), is cited in its entirety in note 83 in a "compare, e.g.," citation for the baleful proposition that civil rights organizations have convinced themselves that Brown stands for desegregation and not education. This and one other "see Bell, supra" cite are the only citations to voices of color in the article. It is as though the author decided he needed a "minority cite," knew what that minority cite should propose, and went out and found it. See also Kenneth L. 
Karst, Citizenship, Race, and Marginality, 30 WM. \& MARY L.REV. 1, 29 n.123 (1988) (citing Bell's Foreword at page four).

Like Moss, Andrew Koppelman, Forced Labor: A Thirteenth Amendment Defense of Abortion, 84 NW. U.L.REV. 480 (1990), uses not only perfunctory citation but also the "I'm So Hip" mechanism. Koppelman cites to almost no authors of the critical persuasion in the bulk of his article, but cites Susan Estrich and Catharine MacKinnon when discussing abortion in cases of rape. See id. at 504 n.104. In notes 109 and 111 he also cites MacKinnon-to a page that is only five pages from the cite in note 104. Apart from these citations and one reference to Adrienne Rich in note 113, no Crits, Critical Race Theory scholars, or radical feminists appear in the article.

[FN58]. See TRIBE, supra note 30, at 920-25 (approaching MacKinnon's Indianapolis ordinance as a First Amendment problem); Cass R. Sunstein, Pornography and the First Amendment, 1986 DUKE L.J. 589, 589-627 (analyzing anti-pornography legislation under the First Amendment and concluding that it is constitutional if narrowly aimed at immediate harms to women).

[FN59]. See, e.g. Catharine A. MacKinnon, Not a Moral Issue, 2 YALE L. \& POL'Y REV. 321, 32145 (1984) (discussing the way that pornography institutionalizes inequality against women); Catharine A. Mackinnon, Pornography, Civil Rights, and Speech, 20 HARV. C.R.-C.L. L.REV. 1, 1 (1985) (same). To be sure, criminalization of pornography that degrades women has a First Amendment dimension, but to treat it, as some do, exclusively under that rubric is to miss much of MacKinnon's message.

[FN60]. See Kingsley R. Browne, Title VII as Censorship: Hostile-Environment Harassment and the First Amendment, 52 OHIO ST. L.J. 481 (1991) (treating various proposals to regulate hatespeech as first amendment problems exclusively).

[FN61]. See Derrick Bell \& Richard Delgado, Minority Law Professors' Lives: The Bell-Delgado Survey, 24 HARV. C.R.-C.L.L.REV. 349, 357-58 (1989) (discussing selective forgetfulness).

[FN62]. See, e.g., Lloyd Cohen, A Different Black Voice in Legal Scholarship, 37 N.Y.L. SCH.L.REV. (forthcoming 1992) (describing Randall Kennedy's critique of Bell, Delgado, and Matsuda).

[FN63]. See, e.g., Aleinikoff, supra note 30 (citing Steve Smith with regard to feminism-a rare lapse because the author cites Matsuda, Olsen, Guinier, and MacKinnon elsewhere in the article); Alex M. Johnson, Jr., The New Voice of Color, 100 YALE L.J. 2007, 2023 (1991) ("According to Sunstein, the difference strand of Critical Feminist Theory is. . . ."); Laurence H. Tribe, The Curvature of Constitutional Space, 103 HARV.L.REV. 1, 15 n.60 (1989) (citing Sunstein for the principle of difference, which is commonly associated with feminist authors).

[FN64]. See Aleinikoff, supra note 30.

[FN65]. See Mari J. Matsuda, Looking to the Bottom: Critical Legal Studies and Reparations, 22 HARV. C.R.-C.L.L.REV. 323 (1987); see also Mari J. Matsuda, Public Response to Racist Speech: Considering the Victim's Story, 87 MICH.L.REV. 2320 (1989) (advocating sensitivity toward outgroups victimized by hate-speech).

[FN66]. I am not saying that men may not write about women's experience or whites about those of people of color. I am saying that it is nice also to cite the originator of an idea. Moreover, often the original version will be more vivid and detailed than that of paraphraser or interpreter, and hence offer the best exposition of the view in question.

[FN67]. For a sparkling, if somewhat acerbic, treatment of this issue, see Trina Grillo \& Stephanie M. Wildman, Obscuring the Importance of Race: The Implication of Making Comparisons Between Racism and Sexism (or other -isms), 1991 DUKE L.J. 397, 401-12. 
[FN68]. Perhaps he was insulted for being short or excluded from a Little League team for lack of athletic ability. See id. at 400-01. I am reminded also of the Clarence Thomas-Anita Hill hearings, in which the nominee succeeded in depicting himself as the victim of harassment.

[FN69]. See Nadine Strossen, Regulating Racist Speech on Campus: A Modest Proposal?, 1990 DUKE L.J. 484, 537 (demonstrating the trite 'no exceptions' argument with the statement that "[t]o attempt to craft free speech exceptions only for racist speech would create a significant risk of a slide down the proverbial 'slippery slope"').

[FN70]. Joanna Russ discusses false categorizing as a mechanism to diminish women's writing. See RUSS, supra note 34 , at 49-61.

[FN71]. See the following reviews of Derrick Bell's book, And We Are Not Saved: Kevin E. Kennedy, Book Review, 86 MICH.L.REV. 1130 (1988) (using terms "stirring" and "poignant" to describe Bell's book); Peter M. Yu, Book Review, 23 HARV.C.R.-C.L.L.REV. 287, 289 (1988) (using terms such as "embellished by the speculation of fiction," "poignan[t]," and "potent"); see also Wendy Kaminer, Citizens of the Supermarket State, N.Y. TIMES, May 26, 1991, § 7 (Book Review), at 10 (reviewing PATRICIA J. WILLIAMS, THE ALCHEMY OF RACE AND RIGHTS (1990)) (stating that Patricia Williams writes with "eloquence" and "passion"). There is nothing wrong with writing powerfully, nor with praising writing that is clean or graphic, but we must not allow our fascination with the vividness of a passage to distract us from the author's meaning, as some do with Critical Race Theory scholarship.

[FN72]. In a contrary mechanism, the author may purport to agree with the writer's call for reform but take issue with the tone in which it is written. It may be dismissed as too despairing, see Alan D. Freeman, Race and Class, 90 YALE L.J. 1880 (1981) (reviewing DERRICK A. BELL, JR., RACE, RACISM AND AMERICAN LAW (2d ed. 1980)); too militant, see Kennedy, supra note 11 , at 1808,1815 , or too extreme, see O'Neil, supra note 38 . Is this Article, for example, audacious or disrespectful? It does speak directly, invents pungent labels for the various mechanisms, and names certain authors who use them. yet, an audacious message may require, or at least justify, an audacious vehicle. Audacity is also a matter of perspective. While some might find some types of Critical writing audacious, it may be more audacious to suggest that the rights of whites not to associate with Blacks are equal in weight to the rights of Blacks to associate with whites, see Herbert Wechsler, Toward neutral Principles of Constitutional Law, 73 HARV.L.REV. 1, 20-35 (1959); that the free-speech right of a racist to hurl invective trumps the right of the victim to be free from receiving it, see Richard Delgado, Words That Wound: A Tort Action for Racial Insults, Epithets, and Name-Calling, 17 HARV.C.R.-C.L.L.REV. 133 (1982); or that affirmative action sacrifices innocent whites in favor of unqualified Blacks. On "innocent" whites and non-innocent blacks, see Richard Delgado, Rodrigo's Chronicle, 102 YALE L.J. (forthcoming 1992).

[FN73]. See Mark Kelman, Concepts of Discrimination in "General Ability" Job Testing, 104 HARV.L.REV. 1158, 1233-34 (1991) (stating that informality increases risk of prejudice, as various Critical Race Theory writers have argued, but "[o]f course, this position has long been taken by some white male critical legal studies scholars as well"); see also Cain, supra note 1 (describing the "what's new" response to feminist writers, in which the author points out that a feminist's work is like other radical theory, or contains nothing original); Martha Minow, Beyond Universality, 1989 U. CHI. LEGAL F. 115, 129 (same observation).

[FN74]. For an example of this type of dismissiveness, see Kaminer, supra note 71, at 10 (implying that Williams uses fancy vocabulary and arcane language to reiterate the obvious fact that racism is bad).

[FN75]. See, e.g., Stephen M. Feldman, Exposing Sunstein's Naked Preferences, 1989 DUKE L.J. 1335,1353 n.87, 1354 n.93, 1355 n.97, 1356 n.99 (citing to Derrick Bell and myself for one 
predictable work each); Linda R. Hirshman, Bronte, Bloom, and Bork: An Essay on the Moral Education of Judges, 137 U.PA.L.REV. 177, 202 n.160, 205 n.178, 217 n.240, 222 n.272, 224 n.285 (1988) (citing MacKinnon for one predictable work); James S. Liebman, Implementing Brown in the Nineties: Political Reconstruction, Liberal Recollection, and Litigatively Enforced Legislative Reform, 76 VA.L.REV. 349, 356 n.37, 359 n.51 (1990) (citing Bell for one predictable work).

[FN76]. SUSAN ESTRICH, REAL RAPE (1987).

[FN77]. Matsuda, supra note 65.

[FN78]. BELL, supra note 31.

[FN79]. The Imperial Scholar, supra note 1.

[FN80]. See RUSS, supra note 34, at 62-75 (Chapter 7-Isolation) (describing a similar phenomena in women's literature-"she wrote it, but she only wrote one of it").

[FN81]. See id. at 69-75 (describing the phenomenon of women being categorized as something other than writers, or else as occasional labored imposters).

[FN82]. See Michel Rosenfeld, Decoding Richmond: Affirmative Action and the Elusive Meaning of constitutional Equality, 87 MICH.L.REV. 1729 (1989). The author rolls merrily along his jurisprudential way, citing Fiss, Bickel, Dworkin, Ely, and then brings in Kimberle Crenshaw for the only cite to a Critical Race Theory figure in the entire article. The proposition he cites her for? "Thus, for example, if the racist portrays blacks as being lazy and irresponsible . . . ." Id. at 1768 n.183. Surely Crenshaw had something more vital to say about our system of white-overblack subordination than that racists often portray blacks as lazy and irresponsible. Also, one would presume that more than one minority scholar has something relevant and significant to say about affirmative action.

[FN83]. For examples of the hostility Critical Race Theory has generated, see Rothfeld, supra note 12; Wiener, supra note 2; Micaela diLeonardo \& Adolph L. Reed Jr., 'Academic PovertyPimping,' NATION, Oct. 23, 1989, at 442 (categorizing certain African-American scholarship as "muddle-headed, self-aggrandizing slop"). But see Rothfeld, supra note 12, at B6 (describing the remarks of Kenneth Karst, a professor who was singled out as an inner-circle member, who called the new movement "inevitable" and "a kind of growth").

[FN84]. See, e.g., Rothfeld, supra note 12, at B6 (citing an anonymous law professor, who stated that new minority writers do not "advance legal scholarship" by mere storytelling and that genuine scholarship is the sort of thing one could cite in a brief to Justice O'Connor).

[FN85]. See, e.g., Symposium, The Critique of Normativity, supra note 31 (describing the change in tenor of legal scholarship away from routine normative work and toward more skeptical and self-reflective analyses of legal cultures and thought); Richard Delgado, Storytelling for Oppositionists and Others: A Plea for Narrative, 87 MICH.L.REV. 2411 (1989) (describing Critical Race Theory and other "outgroup literature"); Jean Stefancic \& Richard Delgado, Outsider Jurisprudence and the Electronic Revolution: Will Technology Help or Hinder the Cause of Law Reform?, 52 OHIO ST. L.J. 847 (1991) (discussing the change in legal scholarship through the writing of Critical Race Theory scholars and electronic technology).

[FN86]. See Richard Delgado, Moves, 139 U.PA.L.REV. 1071, 1072-75 (1991); see also Pierre Schlag, Normative and Nowhere To Go, 43 STAN.L.REV. 167 (1991) (characterizing all of the dominant genre of legal scholarship as empty and passe).

[FN87]. See, e.g., Delgado, supra note 85; see also POLITICS OF LAW, supra note 31 
(containing a collection of articles produced by criticalists and outsiders).

[FN88]. The classic work describing this phenomenon is THOMAS KUHN, THE STRUCTURE OF SCIENTIFIC REVOLUTIONS (2d ed. 1970); see also Delgado, supra note 86, at 1073

("Paradigms change when everyone realizes . . . that [the new paradigm's] advantages outweight the costs of abandoning old assumptions."); Richard Delgado \& Jean Stefancic, Norms and Narratives: Can Judges Avoid Serious Moral Error?, 69, TEX.L.REV. 1929, 1929-34 (1991) (arguing that paradigms change slowly; judges rarely see the dominant forms of injustice and racism of their times as troublesome).

[FN89]. See generally Delgado, supra note 86, at 1072-74 (describing various ways in which some scholars deal with the "new critique").

[FN90]. For descriptions of narrative theory, see ON NARRATIVE (W.J.T. Mitchell ed., 1981); 1 \& 2 PAUL RICOEUR, TIME AND NARRATIVE (1984-85); Robin West, Jurisprudence as Narrative: An Aesthetic Analysis of Modern Legal Theory, 60 N.Y.U.L.REV. 145 (1985).

[FN91]. See Delgado, supra note 85, at 2411-16; Richard Delgado \& Jean Stefancic, Why Do We Tell The Same Stories?: Law Reform, Critical Librarianship, and the Triple Helix Dilemma, 42 STAN.L.REV. 207, 207-09 (1989); see also Steven L. Winter, Contingency and Community in Normative Practice, 139 U.PA.L.REV. 963, 971-1002 (1991) (arguing that structures of legal thought often determine content).

[FN92]. See supra notes $81-82 \& 86$. Jean Stefancic and I have explored the dark side of this observation. See Delgado \& Stefancic, supra note 88, at 1952-56.

[FN93]. See, e.g., Derrick Bell, The Price and Pain of Racial Perspective, STAN. L. SCH. J., May 8,1986 , at 5 (discussing a reaction by some Stanford Law School faculty to Bell's teaching of constitutional law; faculty members offered supplemental classes to Bell's students); see also Delgado, supra note 85, at 2413-16, 2435-38 (arguing that internalized stories determine beliefs); Delgado \& Stefancic, supra note 88, at 1933 (discussing resistance to new narratives).

[FN94]. See BELL, supra note 31, at 102-39. The formula holds that whites will support or tolerate racial justice for blacks only when this coincides with white self-interest. See also BELL, supra note 72 , at 1-71 (describing the same hypothesis).

[FN95]. See Richard Delgado, Our Better Natures: A Revisionist View of Joseph Sax's Public Trust Theory of Environmental Protection, and Some Dark Thoughts on the Possibility of Law Reform, 44 VAND.L.REV. 1209, 1223-27 (1991) (arguing that we resist new thought until it has lost its power to transform us).

[FN96]. See id. at 1223-26.

[FN97]. See id.; cf. Delgado \& Stefancic, supra note 91, at 222-25 (discussing how "[w]e can sometimes break the cycle of repetitive thought and scholarship and achieve genuine innovation"); see also Delgado \& Stefancic, supra note 88, at 1930 ("Only hindsight, benefitted by increased empathy and understanding, exposes an opinion as monstrous, anomalous-a moral abomination.").

Do those who are advocating the new paradigm and attacking the old one demonstrate the same clubby, self-citation vices, the same marginalizing techniques, I have shown on the part of the old guard? An intriguing question, but I did not explore it; my purpose was to identify mechanisms that interfere with legal and social reform, not ones that interfere with stasis. I have the following general impressions: (1) feminists and crits probably cite mainstream writers more often than they us, because (a) there are many more of them, and (b) much of our scholarship is concerned with the defects and hidden assumptions of majority culture, institutions, and legal doctrine; (2) we probably cite nontraditional sources-Gramsci, each 
other, W.E.B. DuBois, etc.-more often than do most mainstream writers; and (3) when we do cite other crits and scholars of color in, say, $40 \%$ of the footnotes of an article, this will strike many majority readers as troublesome (akin to the reaction some have on entering a campus or high-school cafeteria: "Why are all the Blacks sitting together?" failing, of course, to notice that the whites are doing that, as well).

140 UPALR 1349

END OF DOCUMENT 